\title{
Pengaruh Kelekatan Aman Anak pada Ibu terhadap Kemandirian Anak Usia 5-6 Tahun
}

\author{
Mujiwat Amin1, Dian Kristiana ${ }^{2}$, M. Fadlillah ${ }^{{ }_{3}}$ \\ Pendidikan Guru Pendidikan Anak Usia Dini, Universitas Muhammadiyah Ponorogo \\ DOI: $\underline{10.31004 / \text { obsesi.v5i1.504 }}$
}

\begin{abstract}
Abstrak
Orang tua menjadi tumpuan utama pada kelekatan aman setiap anak. Penelitian ini bertujuan untuk mengetahui seberapa besar pengaruh kelekatan aman anak pada ibu terhadap kemandirian anak usia 5-6 tahun. Penelitian ini merupakan penelitian kuantitatif dengan teknik analisis regresi linier sederhana. Teknik pengambilan sampel dengan cara sampling purposive yaitu anak usia 5-6 tahun (kelas B). Subjek pada penelitian ini 23 anak kelompok B TK PKK Banaran, Ponorogo. Teknik pengumpulan data menggunakan kuesioner dengan instrumen berupa skala kelekatan aman dan skala kemandirian. Teknik analisis data penelitian ini meliputi uji normalitas, uji linearitas, uji heterokesdastisitas, uji regresi linear sederhana untuk menguji dan membuktikan hipotesis penelitian. Analisis data dalam penelitian ini menggunakan bantuan SPSS versi 16.Temuan penelitian ada pengaruh positif dan signifikan antara kelekatan aman anak pada ibu terhadap kemandirian anak usia 5-6 tahun dengan nilai $\mathrm{F}_{\text {hitung }}$ sebesar 14.883 dengan tingkat signifikansi 0.001 yang berarti hasil analisis dalam penelitian ini $\mathrm{H}_{0}$ ditolak dan $\mathrm{H}_{\mathrm{a}}$ diterima.
\end{abstract}

Kata Kunci: kelekatan aman; kemandirian; anak usia dini.

\begin{abstract}
Parents are the main focus oe each children secure attachment. This study aims to determine how big the effect of children's secure attachment to the mother toward the independence of children aged 5-6 years. This research is a quantitative approach with a simple linear regression analysis techniques. The sampling technique was purposive sampling namely children age 5-6 years (Kelas B). The subjects in this research were 23 children in Kelompok B TK PKK Banaran, Ponorogo. The data collection techniques use questionnaires with instrument in the form of secure attachment scale and independence scale. Data analysis techniques in this study include normality test, linearity test, heterokesdasticity test, and simple linear regression test to test and prove the research hypothesis. Analysis of the data in this study using SPSS Version 16. The result is a positive and significant influence between the child's secure attachment to the mother towards the independence of children aged 5-6 years with $\mathrm{F}$ value of 14.883 with a significant level of 0.001 , which means the results of the analysis in this study $\mathrm{H}_{0}$ rejected and $\mathrm{H}_{\mathrm{a}}$ accepted.
\end{abstract}

Keywords: secure attachment; independence; early childhood.

Copyright (c) 2020 Mujiwat Amin, Dian Kristiana, M. Fadlillah

$\triangle$ Corresponding author :

Email Address : fadly_ok@yahoo.co.id (Ponorogo, Jawa Timur, Indonesia)

Received 21 March 2020, Accepted 10 May 2020, Published 12 May 2020 


\section{PENDAHULUAN}

Anak adalah karunia Tuhan yang diciptakan untuk dirawat, dibina, dan dididik untuk mencetak generasi mendatang yang memiliki sumber daya manusia berkualitas. Anon (2002) menyebutkan yang termasuk dalam kategori anak adalah seseorang yang belum berusia 18 (delapan belas) tahun, termasuk anak yang masih dalam kandungan. Setiap anak memiliki karakteristik yang khas dan unik serta tidak bisa disetarakan dengan orang dewasa. Untuk itu, orang tua memiliki kewajiban untuk memberikan perhatian dan didikan dalam proses tumbuh kembang anak, baik secara jasmani maupun rohani.

Pada dasarnya setiap anak memiliki potensi yang perlu dikembangkan. Salah satunya yaitu kemandirian. Kemandirian adalah kemampuan individu untuk mampu mengendalikan dan mengatur pikiran, perasaan dan tindakan sendiri secara bebas serta berusaha sendiri untuk mengatasi perasaan-perasaan malu dan keragu-raguan (Desmita, 2012, p. 185). Kemandirian memberikan dampak yang positif bagi perkembangan individu dimasa sekarang dan masa yang akan datang. Dengan demikian, maka tidak ada salahnya jika kemandirian sudah mulai ditanamkan pada diri anak sejak usia dini. Di samping itu, dengan adanya perkembangan ilmu pengetahuan dan teknologi dewasa ini menuntut setiap orang untuk hidup secara mandiri, karena semakin ketatnya persaingan global. Oleh karena itu diharapkan setiap anak dapat mempunyai kemandirian agar mampu menyelesaikan masalah yang dihadapi tanpa perlu bantuan orang lain.

Menurut Asrori (Rantina, 2015:185) kemandirian merupakan salah satu aspek penting yang perlu dimiliki oleh setiap individu, sebab selain dapat berpengaruh terhadap kinerjanya, kemandirian juga berfungsi untuk membantu mencapai tujuan hidup, kesuksesan, prestasi, serta penghargaan. Apabila tidak memiliki kemandirian, maka akan menghambat anak dalam menggapai cita-cita dan meraih kesuksesan.

Yang pertama kali dapat memberikan bimbingan mandiri kepada anak adalah lingkungan keluarga terutama ibu. Kemandirian dapat dikembangkan melalui berbagai latihan-latihan yang dilakukan secara bertahap (Puryanti, 2013). Latihan-latihan tersebut dapat dilakukan dengan memberikan pembiasaan untuk melakukan tugas sederhana sesuai dengan tahapan perkembangan anak dan mudah untuk dilakukan. Misalnya mandi sendiri, memakai baju sendiri, mengancingkan baju, menali sepatu, makan tidak disuapi, membereskan mainan setelah digunakan, pergi ke kamar mandi sendiri, dan kegiatankegiatan ringan yang dilakukan sehari-hari. Sri Rumini dan Siti Sundari dalam bahwa anak yang mandiri memiliki ciri-ciri sebagi berikut: Anak mampu makan dan minum sendiri, memakai sepatu sendiri, mampu menyisir rambut sendiri, bertanggung jawab dengan apa yang ia sukai. Karena setiap orang tua ingin berhasil dalam mendidik kemandirian anaknya (Nurhayati, 2015).

Namun, dalam praktiknya pembiasaan dalam mendidik anak untuk mandiri banyak mengalami hambatan, termasuk campur tangan dari orang tua (ibu). Sehingga akan membuat anak menjadi semakin lekat dengan orang tua dan menjadikan anak kurang mandiri. Hubungan orang tua dan anak yang terlalu lekat akan menimbulkan kecemasan dan takut jika ditinggal ibunya. Anak akan selalu membutuhkan seseorang yang dapat memberi perlindungan sehingga anak merasa aman. Anak akan merasa aman apabila melihat sosok figure lekatnya. Dalam menyampaikan rasa kasih sayang pada anaknya, sebaiknya orang tua tidak selalu memberi bantuan ketika anak mengerjakan tugas. Sebaiknya orang tua memberikan kepercayaan kepada anak untuk menyelesaikan tugas sesuai kemampuan yang dimiliki. Ibu hanya cukup mendampingi saja (Nurhayati, 2015).

Kelekatan aman orang tua menjadi tumpuan utama dalam menjelajah lingkungan baru dan orang asing menjadi penghambatnya. Apabila orang tua berpergian anak merasa cemas dan menangis sebagai cara agar orang tua kembali. Kembalinya orang tua ini semestinya anak melakukan interaksi, apabila masih merasa cemas anak mungkin menginginkan untuk dipeluknya (Upton 2012: 88). 
DOI: 10.31004/obsesi.v5i1.504

Pada kenyataannya, para orang tua khususnya ibu tidak tega melihat anaknya mengalami kesulitan ketika anak melakukan kegiatan, seperti saat anak memakai sepatu, sering kali ibu membantu memakaikan sepatu anaknya, apabila anak belum selesai mengerjakan tugas ibu ikut turun tangan untuk menyelesaikan tugas sekolah, dan sebagainya. Dengan demikian, hal ini tidak akan membantu anak untuk menjadi mandiri.

Berdasarkan hasil observasi di TK PKK Banaran pada hari kamis tanggal 08 November 2018, diperoleh informasi bahwa masih ada sekitar 5\% anak usia 5-6 tahun atau siswa kelompok B yang masih belum mampu menunjukkan kemandiriannya. Ketidakmandirian tersebut seperti: anak merasa cemas ketika akan ditinggal oleh ibunya, meminta bantuan guru saat mengerjakan tugas, minta didampingi saat ingin ke kamar mandi, belum mampu merapikan alat permainan ketika selesai bermain, belum bisa merapikan bajunya sendiri, dan belum bisa menali sepatunya sendiri dengan baik. Bentuk ketidakmandirian tersebut hampir setiap hari dijumpai disekolah. Hal tersebut dikarenakan masih ada beberapa anak mempunyai kelekatan yang besar kepada orangtua (ibu) sehingga membuat anak menjadi kurang mandiri.

Muhammad Ali dan Asrori dalam Kuswanto (2016: 26) mengemukakan bahwa kemandirian dipengaruhi oleh beberapa faktor yaitu gen atau keturunan, pola asuh orang tua, dan sistem pendidikan sekolah. Sedangkan menurut Mussen dalam Puryanti (2013) beranggapan bahwa kemandirian salah satunya bergantung pada pola asuh dan kelekatan anak pada orang tua. Kelekatan antara anak dengan ibu dipengaruhi oleh beberapa faktor, adapun faktor-faktor yang menyebabkan munculnya kelekatan, yaitu terdapat 3 pola kelekatan diantaranya: Kelekatan aman,kelekatan melawan/ambivalen dan kelekatan menghindar Bowlby dalam Cenceng (2015: 148).

Kelekatan terbentuk atas dasar beberapa proses. Proses pembentukan kelekatan didasarkan pada kepercayaan anak terhadap penerimaan lingkungan akan mengembangkan kelekatan yangaman dengan figure lekatnya dan mengembangkanrasa percaya tidak hanya pada ibu dan lingkungan. Hal ini akan berdampak positif terhadap proses perkembangan anak. Anak dengan pola kelekatan aman akan memiliki kemampuan sosial yang baik pada masa kanak-kanak dan mudah beradaptasi dengan lingkungan sosial. Anak dengan pola kelekatan aman lebih mampu membina hubungan persahabatan yang intens, interaksi yang harmonis, responsive dan tidak mendominasi (Ervika, 2005). Menurut Ainsworth dalam Crain (2007:81), kelekatan aman ini mampu membuat anak yakin, senang dan tenang pada orang tua dengan alasan orang tua yang responsif dan sensitif tehadap anaknya

Selain itu anak dengan pola kelekatan aman akan lebih mampu menyelesaikan tugas yang sulit dan tidak mudah berputus asa, serta akan mengembangkan hubungan yang positif berdasarkan rasa percaya (trust) kepada guru dan teman sebaya. Sedangkan, orang tua yang kurang menyenangkan akan menjadikan anak merasa curiga (mistrust) dan mengembangkan kelatan yang tidak aman. Kelekatan tidak aman menjadikan anak tidak percaya (mistrust) pada guru dan teman sebaya, sehingga berakibat terhadap perkembangan anak, seperti anak tidak memiliki kepercayaan diri, tidak mampu menyelesaikan tugas dan tidak mandiri (Ervika, 2005). Sejalan dengan pendapat Boyd\&Bee dalam Bastiani, F. N., \& Hadiyati (2018:431) yang menyatakan bahwa individu yang mengembangkan pola kelekatan aman akan lebih mandiri, dibandingkan dengan individu yang memiliki kualitas kelekatan tidak aman.

Berdasarkan persoalan-persoalan di atas penulis tertarik untuk melakukan pengkajian tentang Pengaruh Kelekatan Aman Anak Pada Ibu Terhadap Kemandirian Anak Usia 5-6 Tahun Di TK PKK Banaran, Pulung, Ponorogo. Tujuan dari penelitian ini adalah untuk mengetahui seberapa besar pengaruh kelekatan aman anak pada ibu terhadap kemandirian anak usia 5-6 tahun di TK PKK Banaran, Pulung, Ponorogo. 


\section{METODOLOGI}

Metode penelitian yang digunakan dalam penelitian ini adalah metode kuantitatif. Di mana penelitian ini dimaksudkan untuk mengetahui hubungan antara variabel independen dan dependen (Sugiyono, 2009). Variabel independennya yaitu kelekatan aman, sedangkan variabel dependennya ialah kemandirian anak. Penelitian ini dilakukan di TK PKK Banaran, Pulung, Ponorogo pada semester (II) genap tahun ajaran 2018/2019. Subjek dalam penelitian ini adalah 23 anak kelompok B untuk meneliti variabel kemandirian dan 23 orang tua (ibu) untuk meneliti variabel kelekatan aman.

Teknik pengumpulan data yang digunakan dalam penelitian ini adalah menggunakan skala Likert yang meliputi skala kelekatan aman yang ditujukan kepada orang tua (ibu) untuk memperoleh data kelekatan aman anak pada ibu berdasarkan persepsi ibu terhadap anaknya dan skala kemandirian yang ditujukan kepada guru kelompok B untuk memperoleh data kemandirian anak berdasarkan hasil pengamatan guru di sekolah.

Teknik analisis data dalam penelitian ini yaitu menggunakan analisis regresi linear sederhana. Sebelum dilakukan uji regresi linear sederhana, terlebih dahulu dilakukan uji prasyarat yang meliputi uji normalitas, uji linearitas dan uji heteroskesdastisitas. Perhitungan uji prasyarat dan uji hipotesis dalam penelitian ini menggunakan bantuan aplikasi SPSS 16 for Windows 8.

Metode penelitian pengaruh kelekatan aman anak pada ibu terhadap kemandirian anak usia 5-6 tahun ini dapat digambarkan melalui bagan 1 berikut:

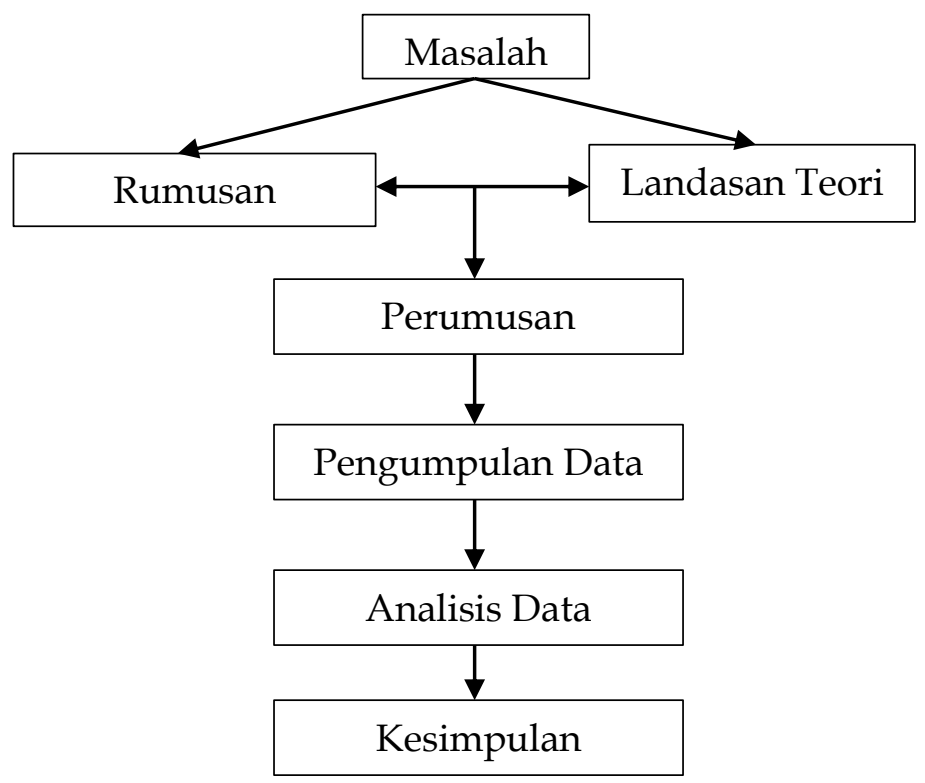

Bagan 1. Desain Penelitian

\section{HASIL DAN PEMBAHASAN}

Pengaruh kelekatan aman anak pada ibu terhadap kemandirian dapat diketahui terlebih dahulu dengan dilakukan ujian prasarat dan uji hipotesis. Uji prasarat meliputi uji normalitas, uji linieritas, dan uji heterokesdastisitas. Hasil dari masing-masing pengujian tersebut sebagai berikut:

\section{Uji Normalitas}

Uji normalitas bertujuan untuk menguji apakah dalam model regresi, sampel yang digunakan dalam penelitian memiliki distribusi normal (Ghozali, 2013). Uji normalitas dalam penelitan ini adalah dengan menggunakan Kolmogorov-Smirnov test. Kriteria pengambilan keputusan yaitu jika probabilitas sig $>\alpha$ maka data berdistribusi normal dan jika nilai probabilitas sig $<\alpha$ maka data berdistribusi tidak normal. Nilai $\alpha$ yang digunakan 
DOI: 10.31004/obsesi.v5i1.504

yaitu 0.05. Berdasarkan hasil uji normalitas dengan uji Kolmogorov-Smirnov test dapat diketahui bahwa nilai signifikansinya adalah 0.976. Terlihat nilai signifikansi $>0.05$, sehingga dapat disimpulkan bahwa data berdistribusi normal.

\section{Uji Linearitas}

Uji linearitas dilakukan untuk mengetahui bentuk hubungan antara variabel yang sedang diteliti (Wibowo, 2012:72). Dasar penentuan keputusan yaitu jika nilai Deviation from Linearity sig. $>0.05$ maka ada hubungan yang liniear secara signifikan antara variabel bebas dengan variabel terikat. Sebaliknya jika nilai Deviation from Linearity sig. $<0.05$ maka tidak adahubungan yang linear secara signifikan antara variabel bebas dengan variabel terikat. Berdasarkan hasil uji linearitas tersebut dapat diketahui nilai Deviation from Linearity Sig $>0.05$ yaitu sebesar 0.528. sehingga dapat disimpulkan bahwa data memiliki hubungan yang linear secara signifikan.

\section{Uji Heterokesdastisitas}

Uji heterokesdastisitas merupakan uji yang digunakan untuk menguji ada tidaknya gejala ketidaksamaan varian dari residual pada pengamatan model regresi (Wibowo, 2012:93). Dasar untuk analisis adalah apabila variabel independen secara statistic signifikan mempengaruhi variabel dependen, dapat terlihat jika nilai sig $<5 \%$ atau 0.05 maka terindikasi heterokesdastisitas dan sebaliknya jika variabel independen tidak mempengaruhi variabel dependen, dengan sig $>5 \%$ atau 0.05 maka tidak terindikasi heterokesdastisitas. Berdasarkan hasil perhitungan heterokesdastisitas diatas dapat diketahui bahwa nilai signifikansinya sebesar $0.278>0.05$, sehingga dapat dikatakan bahwa tidak terdapat gejala heterokesdastisitas pada model regresi.

\section{Uji Hipotesis}

Hipotesis merupakan dugaan sementara berdasarkan rumusan masalah, sehingga perlu dilakukannya pengujian guna mengetahui kebenarannya. Uji analisis statistik yang digunakan adalah menggunkan uji regresi linear sederhana. Dengan dasar keputusan jika nilai Sig > 0.05 maka $\mathrm{H}_{0}$ diterima, sebaliknya jika nilai $\mathrm{Sig}<0.05$ maka $\mathrm{H}_{0}$ ditolak. Perhitungan uji regresi liniear sederhana dalam penelitian ini menggunakan program SPSS 16 for windows 8 . Berdasarkan tabel diatas dapat diketahui besarnya nilai korelasi/hubungan (R) sebesar 0.644 dan nilai koefisien determinasi ( $R$ Square) sebesar 0.415 yang memiliki arti bahwa pengaruh variabel kelekatan aman terhadap variabel kemandirian sebesar $41.5 \%$ dan sisanya dipengaruhi oleh faktor lain seperti lingkungan, stimulus, dan lain sebagainya.

Tabel 1. Hasil Uji F Anovab

\begin{tabular}{lrrrrrr}
\hline Model & Sum of Squares & df & & Mean Square & F & Sig. \\
\hline 1 Regression & 499.923 & 1 & 499.923 & 14.883 & & $.001^{\text {a }}$ \\
Residual & 705.381 & 21 & 33.590 & & & \\
Total & 1205.304 & 22 & & & & \\
\hline
\end{tabular}

\section{Keterangan:}

a: Predictors: (Constant), kelekatan_aman

b: Dependent Variable: kemandirian

Tabel diatas menunjukkan nilai $\mathrm{F}$ hitung sebesar 14.883 dengan tingkat signifikan sebesar $0.001<0.05$. Sehinggadapat dikatakan bahwa $\mathrm{H}_{0}$ ditolak dan $\mathrm{H}_{\mathrm{a}}$ diterima yang artinya bahwa variabel kelekatan aman $(\mathrm{X})$ berpengaruh terhadap variabel kemandirian $(\mathrm{Y})$.

Dari hasil uji regresi linear sederhana diketahui nilai constant (a) sebesar 16.580, dan nilai kemandirian (b/koefisien regresi) sebesar 0.977. Sehingga dapat ditulis persamaan regresinya sebagai berikut:

$$
\begin{gathered}
Y=a+b X \\
Y=16.580+0.977 X
\end{gathered}
$$



berikut:

Penjelasan rumus persamaan regresi linear sederhana tersebut adalah sebagai

a. Nilai Konstanta sebesar 16.580, yang artinya variabel kemandirian memiliki nilai konsisten sebesar 16.580 .

b. Nilai koefisien regresi $X$ sebesar 0.977 , yang artinya setiap penambahan $1 \%$ kelekatan aman, maka kemandirian anak akan bertambah sebesar 0.977 . Koefisien regresi bernilai positif sehingga dapat dikatakan bahwa arah pengaruh variabel $\mathrm{X}$ terhadap variabel $\mathrm{Y}$ adalah positif.

Penelitian ini dilakukan dengan menghimpun data melaluipenyebaran kuesioner kemandirian dan kelekatan aman yangdijadikan sebagai instrument pengumpulandata, dengan jumlahkeseluruhanpernyataan sejumlah 20 butiruntuk skalakemandiran dan 14 butir untuk skala kelekatan aman yang sudah valid dan reliabel. Lembar kuesioner kemandirian dibagikan kepada pendidik kelompok B untuk mencari data kemandirian siswa berdasarkan hasil pengamatan guru disekolah dan kuesioner kelekatan aman dibagikan kepada orang tua (ibu) untuk mencari data kelekatan aman anak pada ibu berdasarkan persepsi ibu terhadap anak.

Setelah hasil kuesioner diperoleh maka tahap selanjutnya adalah menganalisis data, yang bertujuan untuk mengetahui ada tidaknya pengaruh kelekatan aman anak pada ibu terhadap kemandirian anak usia 5-6 tahun di TK PKK Banaran, Pulung, Ponorogo. Adapun tahap analisis data yang dilakukan adalah dengan uji prasyarat analisis dan uji hipotesis.

Pengujian prasyarat terdiri atas tiga tahap, diantaranya yaitu uji normalitas, yang bertujuan untuk mengetahui apakah data berdistribusi normal atau tidak. Uji linearitas, yang bertujuan untuk mengetahui bentuk hubungan antar variabel yang sedang diteliti. Selanjutnya, uji heterokesdastisitas yang bertujuan untuk menguji ada atau tidak gejala ketidaksamaan varian dari residual pada model regresi. Setelah dilakukannya uji prasyarat, maka tahap terakhir yang dilakukan dalam penelitian ini adalah pengujian hipotesis. Analisis yang digunakan dalam penelitian ini adalah menggunakan analisis regresi linear sederhana. Pengujian regresi linear sederhana dengan menggunakan program SPSS.

Berdasarkan hasil pengujian regresi linear sederhana yang telah dilakukan oleh peneliti diperoleh nilai $F_{\text {hitung }}$ sebesar 14.883 dan $t_{\text {hitung }}$ sebesar 3.858 dengan tingkat signifikan atau probabilitas sebesar $0.001<0.05$ sehingga dapat disimpulkan bahwa $\mathrm{H} \alpha$ diterima dan $\mathrm{H}_{0}$ ditolak. Yang berarti bahwa kelekatan aman anak pada ibu berpengaruh terhadap kemandirian anak usia 5-6 tahun di TK PKK Banaran, Pulung, Ponorogo. Kelekatan aman anak pada ibu memberikan pengaruh yang positif dan signifikan sebesar $41,5 \%$ terhadap kemandirian anak usia 5-6 tahun di TK PKK Banaran, Pulung, Ponorogo.

Analisis penelitian ini memberikan gambaran bahwa ada pengaruh yang positif dan signifikan antara kelekatan aman anak pada ibu terhadap kemandirian anak usia 5-6 tahun di TK PKK Banaran, Pulung, Ponorogo. Hasil ini sejalan dengan penelitian yang menyebutkan bahwa terdapat hubungan positif yang signifikan antara kelekatan aman anak pada ibu dengan kemandirian di sekolah (Puryanti, 2013). Temuan ini juga diperkuat dengan penelitian Fauzul yang menyebutkan bahwa ada pengaruh sangat signifikan antara secure attachment terhadap kemandirian anak usia dini (Mutmainah, 2016). Berdasarkan penelitian tersebut dipahami bahwa semakin positif kelekatan anak terhadap ibu, maka semakin tinggi tingkat pencapaian kemandiriannya. Sebaliknya, semakin negatif kelekatan anak terhadap ibu, maka tingkat pencapaian kemandiriannya semakin rendah.

Kelekatan aman orang tua terhadap anak sangat baik untuk melatih dan mengembangkan kemandirian anak di sekolah. Sebuah penelitian menunjukkan bahwa kelekatan ibu terhadap anak sangat penting ketika di sekolah (Hewi, Saleh, \& Wahyuni, 2019 , p. 406). Ada hubungan yang kuat dan signifikan antara kelekatan pada ibu dengan kemandirian anak usi 5-6 tahun (Sari, 2019). Menurut Mussen dalam (Nurhayati, 2015) dijelaskan bahwa kemandirian salah satunya bergantung pada kelekatan anak dengan orangtua. Salah satu bentuk kelekatan yang sangat berpengaruh terhadap kemandirian anak adalah kelekatan aman. Sebagaimana hasil penelitian yang menyebutkan bahwa secure 
DOI: 10.31004/obsesi.v5i1.504

attachment memiliki pengaruh signifikan terhadap kemandirian anak usia dini (Mutmainah, 2016). Hal ini juga diperkuat oleh pendapat Ainsworth bahwa faktor-faktor yang mempengaruhi kelekatan yaitu kelekatan aman (secure attachment), di mana kelekatan ini lebih sensitif dan responsif sehingga anak yakin orang tua selalu ada di saat ia membutuhkan dan anak merasa nyaman (Nurhayati, 2015).

Orang tua yang memiliki kelekatan aman memiliki ciri-ciri sangat responsif dan selalu ada ketika dibutuhkan oleh anak. Anak merasa nyaman dan tenang karena ada yang menjaga dan melindunginya. Menurut Brooks dijelaskan bahwa ketika orang tua (ibu) bersikap peka, responsif, hangat menerima dan penuh perhatian pada ritme perilaku dan individualitasnya, mereka menciptakan pemahaman bersama yang mengembangkan bentuk kelekatan aman orang tua (ibu)-anak (Sari, 2019). Anak dengan pola kelekatan aman paling akan lebih mandiri, tidak mudah putus asa, mampu menangani tugas yang sulit, dan akan mengembangkan hubungan yang positif (Ervika, 2005). Dengan demikian, untuk dapat mengembangkan kemandirian anak, hendaknya orang tua senantiasa memberikan motivasi dan juga perhatian yang dibutuhkan oleh anak. Sebab, peran orang tualah yang paling utama dalam membimbing dan mendidik anak-anaknya. Senada dengan temuan Yasinta Maria Fono bahwa kemandirian anak itu tidak dapat dibentuk tanpa adanya stimulus dari orang tua (Fono, Fridani, \& Meilani, 2019). Dari pembahasan tersebut dapat dipahami bahwa kelekatan aman anak pada orang tua khususnya ibu sangat mempengaruhi perkembangan kemandirian anak usia dini. Oleh karena itu, sikap responsif, peka, peduli dan selalu meluangkan waktu untuk anak sangat diperlukan guna menumbuhkan dan mengembangkan kemandirian mereka.

\section{SIMPULAN}

Ada pengaruh antara kelekatan aman anak pada ibu terhadap kemandirian anak usia 5-6 tahun di TK PKK Banaran, Pulung, Ponorogo. Terdapat tanda positif pada nilai koefisien regresi yang menandakan bahwa kelekatan aman anak memberikan arah yang positif terhadap variabel kemandirian sehingga ada pengaruh yang positif dan signifikan antara kelekatan aman anak pada ibu terhadap kemandirian anak usia 5-6 tahun di TK PKK Banaran, Pulung, Ponorogo.

\section{UCAPAN TERIMAKASIH}

Penulis mengucapkan terimakasih kepada semua pihak yang telah membantu baik secara material maupun non material dalam menyelesaikan penelitian ini. Terutama kepada Kepala Sekolah, guru, orang tua anak didik di TK PKK Banaran, Ponorogo. Selain itu, kepada lembaga TK PKK Banaran, Ponorogo yang telah memfasilitasi segala apapun kebutuhan penulis.

\section{DAFTAR PUSTAKA}

Bastiani, F. N., \& Hadiyati, F. N. R. (2018). Hubungan Kelekatan Orangtua-Remaja Dengan Kemandirian Mahasiswa Tahun Pertama 2017 Fakultas Teknik Universitas Diponegoro. Empati, 429-437.

Cenceng. (2015). Perilaku Kelekatan pada Anak Usia Dini (Perspektif John Bowlby). Lentera, IXX(2), 141-153.

Crain, W. (2007). Teori Perkembangan (Konsep dan Aplikasi). Yogyakarta: Pustaka Pelajar.

Desmita. (2012). Psikologi Perkembangan. Bandung: PT Remaja Rosdakarya.

Ervika, E. (2005). Kelekatan (attachment) pada anak. Universitas Sumatera Utara.

Fono, Y. M., Fridani, L., \& Meilani, S. M. (2019). Kemandirian dan Kedisplinan Anak yang Diasuh oleh Orangtua Pengganti. Jurnal Obsesi : Jurnal Pendidikan Anak Usia Dini, 3(2), 537. https://doi.org/10.31004/obsesi.v3i2.245

Ghozali, I. (2013). Aplikasi Analisis Multivariate Dengan Program IBM dan SPSS 21 (Edisi Tujuh). In Semarang: Universitas Diponegoro. https://doi.org/10.1126/ science.1158668 
DOI: 10.31004/obsesi.v5i1.504

Hewi, L., Saleh, M., \& Wahyuni, R. (2019). Kelekatan (Attachment) Anak Usia Dini di Suku Laut Kabupaten Wakatobi. Jurnal Obsesi : Jurnal Pendidikan Anak Usia Dini, 4(1), 418. https:// doi.org/10.31004/obsesi.v4i1.346

Indonesia, U.-U. R. (2002). Undang-Undang Republik Indonesia Nomor 23 Tahun 2002 tentang Perlindungan Anak dengan. Undang-Undang, 52(1), 1-5.

Kuswanto, Wijaya, C. (2016). Menumbuhkan kemandirian anak usia dini melalui bermain. Ilmiah Pendidikan Islam Anak Usia Dini, 1(2), 20-34.

Mutmainah, F. (2016). Pengaruh secure attachment terhadap kemandirian anak usia dini di RA Muslimat NU 1 Belung Poncokusumo Malang. Universitas Islam Negeri Malang.

Nurhayati, H. (2015). Hubungan Kelekatan Aman (Secure Attachment) Anak pada Orangtua dengan Kemandirian Anak Kelompok B TK PKK 37 Dodogan Jatimulyo Dlingo Bantul. Jurnal Pendidikan Guru Pendidikan Anak Usia Dini, 9(tahun ke-4), 1.

Puryanti, I. (2013). Hubungan kelekatan anak pada ibu dengan kemadirian di sekolah. Universitas Negeri Semarang.

Rantina, M. (2015). Peningkatan Kemandirian Melalui Kegiatan Pembelajaran Practical Life (Penelitian Tindakan di TK B Negeri Pembina Kabupaten Lima Puluh Kota, Tahun 2015). Jurnal Pendidikan Usia Dini, 9, 181-200. https://doi.org/DOI: https:// doi.org/10.21009/JPUD.091

Sari, N. (2019). Hubungan Kelekatan Pada Ibu dengan Kemandirian Anak Usia 5-6 Tahun (Vol. 2). https:/ / doi.org/10.1017/CBO9781107415324.004

Sugiyono. (2009). Metode Penelitian Kuantitatif, Kualitatif dan R \& D. Bandung: Alfabeta.

Upton, P. (2012). Psikologi Perkembangan (N. F. Widuri, Ed.). Jakarta: Erlangga.

Wibowo, A. E. (2012). Aplikasi Praktis SPSS Dalam Penelitian. (A. Djojo, Ed.) (A. Djojo, Ed.). Yogyakarta: Penerbit Gava Media. 